\title{
Reljefni prikazi kola na stećcima
}

Miroslav Palameta

E-pošta:miropal@yahoo.it

Ksenija Palameta, crteži

\author{
UDK: 398
726.825 .04 \\ UDK: 398
726.825 .04 \\ Izvorni znanstveni rad \\ Primljeno: 2. svibnja 2018. \\ Prihvaćeno: 30. svibnja 2018.
}

\section{Sažetak}

Članak o motivu kola na kasnosrednjovjekovnim nadgrobnim spomenicima, koje obično zovemo stećcima, ima nakanu osvijetliti naznačenu problematiku iz semiološke perspektive analizirajući reprezentativne uratke na već poznatim i tek otkrivenim spomenicima. Uz to namjerava preispitivati rezultate dosadašnjih proučavanja i utvrditi nove rezultate. Pri tome polazi od nekoliko općeprihvaćenih stajališta, ponajprije da su ti spomenici preostali dio iz devastiranoga i izgubljenoga kulturološkoga konteksta; da je matični prostor u kome su se ti spomenici pojavili, dakle srednjovjekovna Bosna i Hum, bio otvoren, posebno prema gradovima u primorju, ali i europskim kontinentalnim središtima; da tijekom cijeloga europskog srednjeg vijeka svi ideološki i svjetonazorski obrasci izrastaju i oblikuju se isključivo na kršćanskoj vjerskoj podlozi, što je iznimno važno za kulturu smrti i odnos prema njoj; da su kopizam i citatnost odlika svakoga stvaralaštva u tom vremenu i da najkvalitetnije likovne kompozicije na stećcima nisu projektirane samo na jednu stranu spomenika, nego se često radi o poliptihalnoj projekciji.

Ključne riječi: kontekst; znak; ples; eshatologija; stećak. 
Predstava kola ostala je do danas najmanje osvijetljeno ikonografsko područje vezano za reljefne motive s kasnosrednjovjekovnih nadgrobnih spomenika, bez obzira na volju i zanimanje istraživača. Sam naziv kolo za tri i više ljudskih silueta slične stilizacije koje se drže za ruke na tim spomenicima denotira folklornu razinu pa je etnologija u mnogim radovima postala odgovarajuće područje iz kojega se pokušavala objasniti njihova pojava i smisao. Rezultati većine tih zanimanja mogli bi se svesti na odgovore o lociranju i prebrojavanju ili na pitanja jesu li ta kola muška, ženska ili mješovita; koji je broj plesača i kreću li se ona "naoposun" ili naopako, što bi upućivalo na ilustracije pogrebnoga kola, koje se navodno izvodilo u "balkanskim prostorima". ${ }^{1}$ Potraga za preživjelim performansima folklornih zabava i igara koje su sličile po nekoj pojedinosti na isklesane kompozicije smatrani su važnim doprinosima. Da su ti otkriveni primjeri uglavnom izvan područja stećaka, kod jednoga autora čak na Borneu, nikoga nije zabrinjavalo. Iskorak iz folklornih okvira bio je istraživanje arhivskih podataka o zabavama i igrama mladeži, uglavnom u sakralnim prostorima, u primorskim i mediteranskim gradskim komunama, ali ni ti rezultati po naravi svoje tematike nisu unijeli bilo kakvo novo svjetlo pod kojim bi likovna problematika stećaka postala jasnija.

Za srednjovjekovnim likovnim predstavama kola izvan stećaka nije se posezalo, možda zato što takva likovna građa autorima nije bila poznata ili su pojedine predstave sa svojim jasnim interpretacijama kolidirale $s$ njihovim unaprijed zamišljenim značenjima reljefnih uradaka. Ipak, povorke svetaca, isklesane na portalima sjevernotalijanskih i francuskih romaničkih crkava kako promatraju Krista na nebeskom prijestolju ili pri uzašašću, često izgledaju kao kola zanesenih igrača. Kada bi se izdvojila kamena greda iznad vrata Miègeville u bazilici Saint-Sernin u Toulouseu, na kojoj su apostoli ispod lunete koja prikazuje upravo Kristovo uzašašće, teško bi bilo zaključiti da se ne radi o plesačima koji plešu uzdignute glave u jedinstvenom ritmu pokreta (Sl. 1). Tek ključevi u ruci jednoga od tih likova, atribut sv. Petra, upućivao bi na njihov identitet.

1 ŠEFIK BEŠLAGIĆ, Kupres, srednjevjekovni nadgrobni spomenici Bosne i Hercegovine, V., Zemaljski zavod za zaštitu spomenika kulture i prirodnih vrijednosti BiH, Sarajevo, 1954., str. 184-185; IvAN Mužić, "Vlasi i starobalkanska pretkršćanska simbolika jelena na stećcima", u: Starohrvatska prosvjeta, III. serija - svezak 36, Split, 2009., str. 334; Dubrav ko Lovrenović, Stećci bosansko i humsko mramorje srednjeg vijeka, Rabic, Sarajevo, 2009., str. 73, 207. 


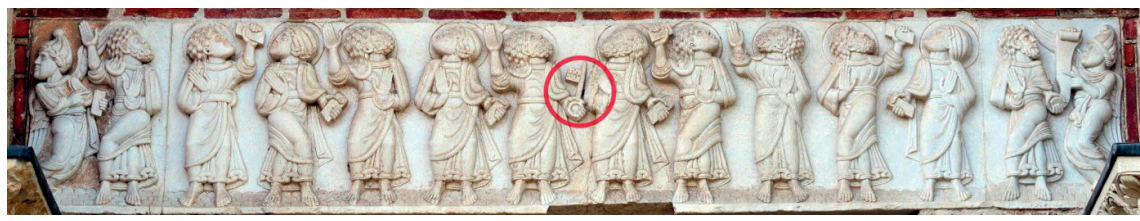

S1. 1.

Sličan dojam ostavlja i jedna kompozicija u Mletačkom zborniku, ${ }^{2}$ bosaničkom rukopisnom zborniku, ispred teksta Djela apostolskih (Sl. 2). Jedanaest izduženih i shematiziranih ljudskih likova u dugim haljinama-togama, naslikanih plošno s uzdignutim pogledom prema vrhu sljedeće stranice rukopisa iznad početka Djela apostolskih, podsjećaju sugestivno na kola s kamenih spomenika.

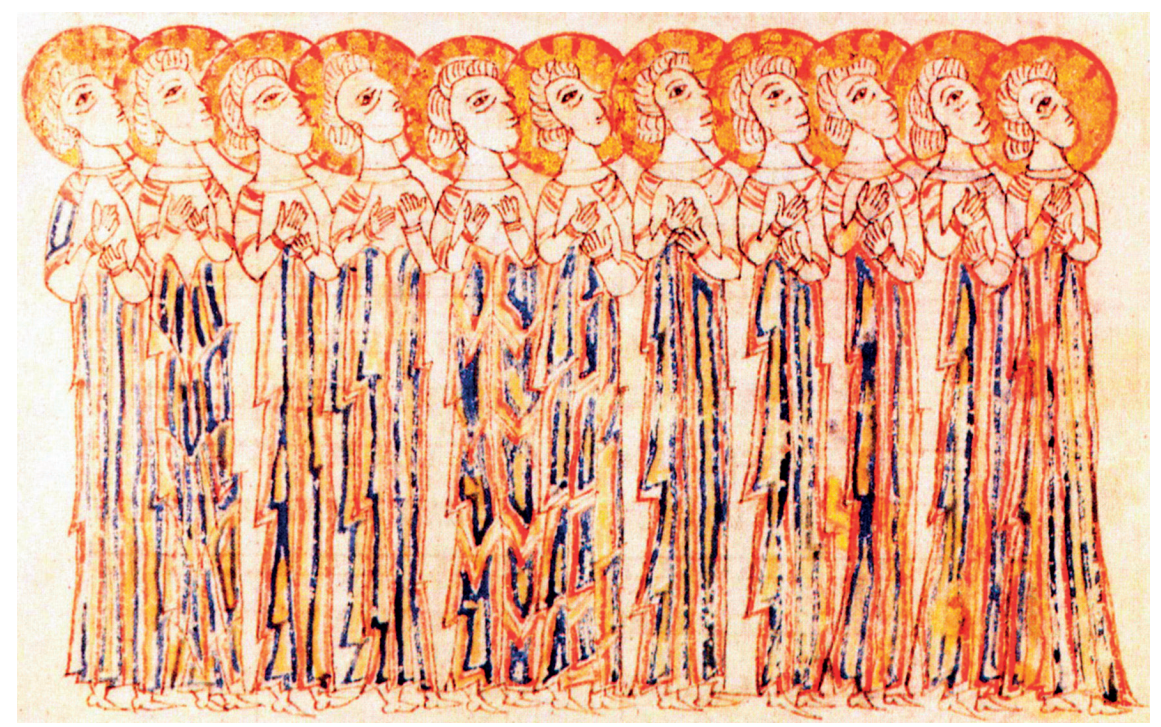

Sl. 2.

Da prizor nije dio jedinstvenoga diptiha i da likovi nemaju iscrtane gotičke aureole, on bi se jednostavno mogao interpretirati kolom. Dakako, to nije ni kor pjevača ni kolo s plesačima, nego jedanaest apostola koji slijede pogledom pravac kažiprsta dvojice kerubina iznad njih prema bosonogom Kristu na cvjetnom prijestolju s početka sljedeće stranice, kao na reljefu iz Toulousea. Činjenica da je slikar

2 Simonetta Pelusi (izd.), Novum Testamentum Bosniacum Marcianum. Cod. Or. 227, Editoriale Programma, Verona, 1991. 
$\mathrm{u}$ oba navedena primjera koncipirao kompoziciju u formi povorke ili kola kako bi joj unutar tematskoga konteksta pridružio određeno značenje, nije ni najmanje neobično, posebice u romaničkoj tradiciji koja se prepoznaje i u kompoziciji reljefnih predstava na kasnosrednjovjekovnim nadgrobnim spomenicima. Odsutnost prostorne i uvažavanje vertikalne perspektive posebno pridonosi takvim dojmovima. Postoje prizori kola s prizorima lova na jelena u jedinstvenim kompozicijama, kao na stećku s Mirkove kose kod Kalinovnika, ${ }^{3}$ što iz perspektive suvremena promatrača i njegova horizonta očekivanja izaziva nedoumicu o autorskoj intenciji. Tu je isklesano devet ljudskih silueta kako se drže za ruke iznad košute i dva jelena u trku, pa se u prvom dojmu toga istog promatrača pojavljuje asocijacija na hajkače koji usmjeravaju lovinu. Prisjeti li se u tom trenutku da je autoru toga prizora bio uzor možda neki salonitanski rimski sarkofag, čiji je agonistički prizor lova na istu divljač kopirao netko davno po pravilima svoga likovnog poimanja, razdvajajući ljudske i životinjske likove i u duhu spomenute perspektive, pomislit će se da na tom spomeniku možda i nisu prikazani očekivani plesači.

Likovnih predstava s istom temom ima cijeli niz, lošije i kvalitetnije izradbe, odnosno različite stilizacije. Jedan od najljepših niski je sanduk s najranijega dijela nekropole na Radimlji (Sl. 3). Njegov majstor je iz radionice koja je izrađivala spomenike u širokom potezu donjohercegovačkih nekropola od Neretve do vrela Trebišnjice, prepoznatljive po skladnim likovima ljudi i životinja u plitkom reljefu, stiliziranim u maniru gotičkih minijatura. On je istu temu obradio u triptihalnoj formi i prelomio je na tri strane spomenika. Razdvojio je kolo na dvije jednake skupine sudionika koje uokviruju središnji prizor s košutama u bijegu od psa prema skrivenom strijelcu što ih sačekuje na rubu slike. Sva tri dijela objedinjuje ista i prepoznatljiva trolisna bordura s gornje strane.
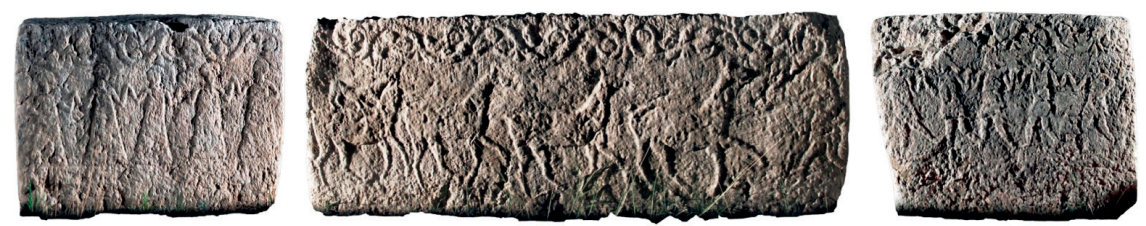

S1. 3.

Marian Wenzel, Ukrasni motivi na stećcima, Veselin Masleša, Sarajevo, 1965., XCVI., br. 26. 
Navedeni primjeri upućuju da uspostavljeni kriteriji svrstavanja likovnih predstava na stećcima u pojedine skupine nisu pouzdani. $U$ tom smislu dovoljno je spomenuti nekoliko spomenika iz najpoznatijega kataloga koji je sastavila Marian Wenzel. Ona je cvjetni friz čiji se listovi spajaju na spomeniku Ljupka Vlasnića iz Troskota svrstala u predstave ženskoga kola (XCIII, 10), a u mješovito kolo predstavu s jednoga stećka na Blidinju, na kojemu, uz još dvije ljudske siluete, muškarac zamahuje mačem prema dječačkom liku, držeći ga lijevom rukom za kosu (XCVI, 29), što bi moglo predstavljati prikaz pokolja nevine dječice kao na skulpturama brojnih romaničkih kapitela. $\mathrm{Ni}$ predstava od tri lika s astralnim simbolima oko glave na još jednom blidinjskom spomeniku (XCIV, 10), kao ni nejasna kompozicija na sanduku iz Podgradinja u Gornjem Hrasnu (XCVI, 10), ne bi se dale prepoznati kao kolo. Pristupi li se i nedvosmislenim piktogramima kola na stećcima iz perspektive znaka, onda će samo biti sigurno da je utvrđen označitelj, dok značenje valja tek dekodirati iz užega i širega konteksta, čime će se članak baviti do svoga kraja.

\section{Srednjovjekovni likovni i kulturološki kontekst}

U literaturi o stećcima reljefne predstave kola nisu se temeljitije dovodile u bilo kakav suodnos s likovnim tradicijama srednjega vijeka. Tek asocijacije na mrtvački ples (dance macabre) pri tom djeluju uglavnom kao ekspresije koje bi trebale jamčiti autorovu upućenost $\mathrm{u}$ problematiku. One nemaju ni u jednom slučaju ulogu dozivanja bilo kakvih podudarnosti ili čak otklanjaju moguće dodirnice. Ipak, predstave plesa i kola u likovnoj srednjovjekovnoj umjetnosti nisu rijetkost kao što se mislilo. Naprotiv, susreće se i u palačama i u crkvama, na freskama, platnima i u kamenoj plastici. U oslikanim rukopisima profanoga i pobožnoga sadržaja, na njihovim rubovima kao osobita dekoracija ili kao ilustracija teksta. Tako se samo u oksfordskom rukopisnom Romanu o Aleksandru, ${ }^{4}$ vrlo popularnom srednjovjekovnom štivu, nalazi petnaestak minijatura izvrsnoga flamanskog iluminatora Jehana de Grisea koje prikazuju kolo u različitim stilizacijama i oblicima (Sl. 4). Naslikane na marginama, neovisno o sadržajima teksta, one su čiste autorske kreacije koje bi se mogle interpretirati imaginarijem o vašarskom zabavnom životu zapadnjačkoga svijeta XIV. stoljeća.

4 Roman o Aleksandru, Oxford, Bodleian Library MS. Bodl. 264, fol. 97v. 


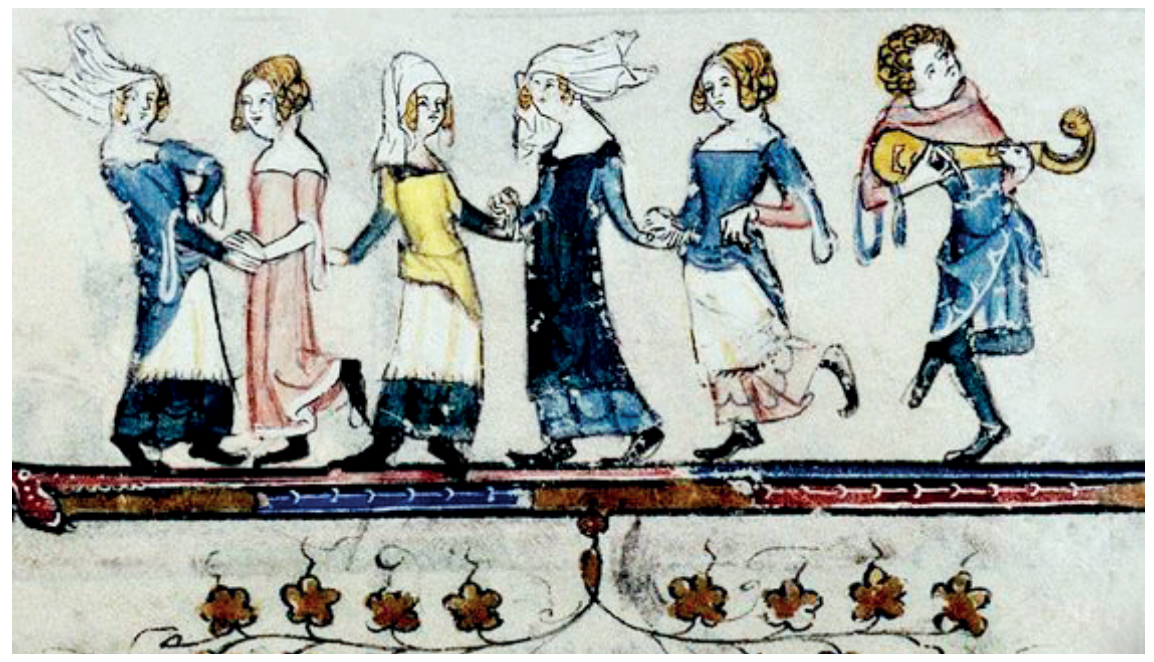

S1. 4.

Međutim, prikazi kola u brojnim iluminiranim rukopisima Romana o ruži (Roman de la Rose), koji se pripisuje Guillaumeu de Lorrisu, prikazuju redovito niz mladića i djevojaka kako se drže za ruke u plesnom pokretu (Sl. 5). Središnja muška figura ima krunu na glavi i uzdignuta anđeoska krila. Nema sumnje da prikaz plesnih pokreta i odjeće odražava stvarnu igru i modu XIV. stoljeća otmjenoga plemićkog zapadnjačkog svijeta, ali ta minijatura iz Romana o ruži, koja se obično zove Ples u Deduovu vrtu, ${ }^{5}$ nema konačnu namjeru prikazati takve činjenice, iako su sadržane u njoj, nego predočiti alegoriju mladosti kojom upravlja krilati Amor.

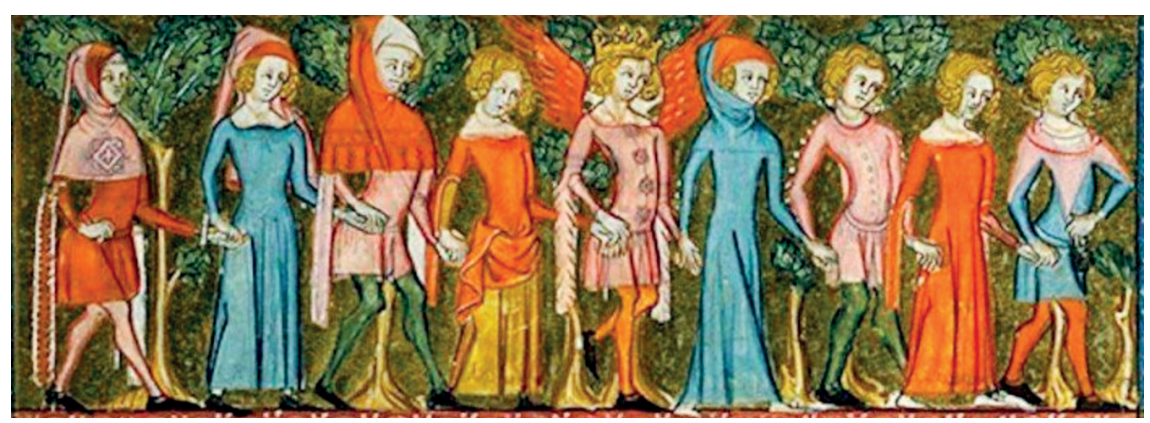

Sl. 5.

5 Guillaume de Lorris, Roman de la rose, Bibliothèque nationale de France, Galica, fr 1567, f, 7r. 
Posve je razumljivo da se u ljubavnoj romanesknoj problematici, odnosno njezinu kontekstu, pojavi takva likovna kompozicija. Premda pokreti tih krhkih mladenačkih figura podsjećaju na siluete plesača s nadgrobnih kamenih spomenika po Hercegovini, nezamislivo je da se tim reljefnim predstavama pripisuje neko slično značenje, jer funeralni kontekst s nedvojbenim kršćanskim eshatološkim poimanjem upućuje na posve drugačiji smisao.

U srednjovjekovnim iluminiranim rukopisima i u slikarstvu predrenesanse pojavljuje se taj isti motiv s jasnim eshatološkim smislom. $U$ Teodorovu psaltiru (Theodore Psalter) iz XI. st. prikazana su petorica svetaca $s$ teškim zlatnim aureolama kako u živom pokretu tijela i udarajući dlanom o dlan plesom izražavaju doživljaj rajskoga blaženstva (Sl. 6). ${ }^{6}$

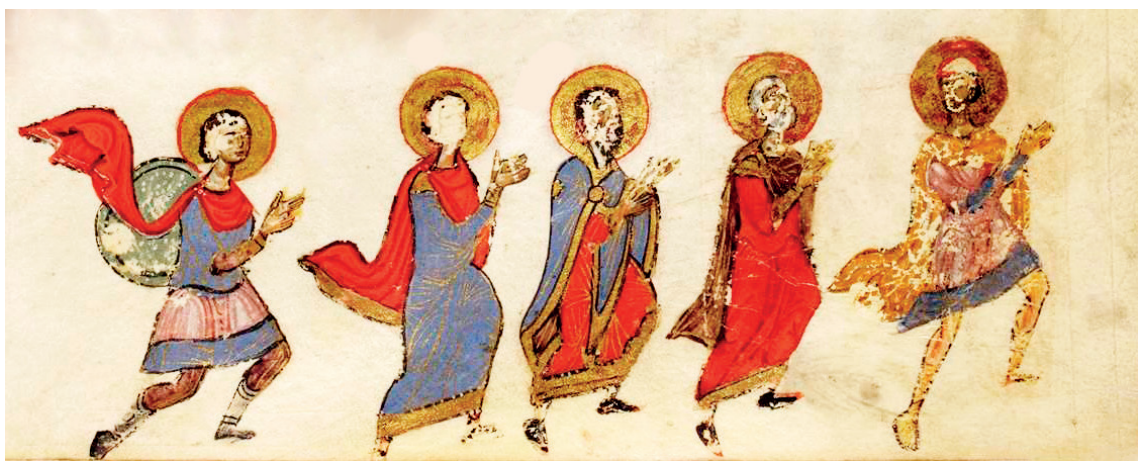

S1. 6.

Iz istoga stoljeća je i bogato ilustriran rukopis komentara Ivanove Apokalipse u kojem se na nekoliko mjesta prikazuju svetački likovi u plesu. ${ }^{7}$ U jednoj kompoziciji trinaest svetačkih figura s isprepletenim rukama na prsima igraju kolo (Sl. 7), ispod njih deset likova s aureolama i u drugačijem rasporedu plešu, dok je na dnu stranice prikazan vodeni bezdan $\mathrm{s}$ bezbojnim osuđenim dušama.

6 Teodorov psaltir, Add MS 19352, f. 158r.

7 Beato de LiÉbana, Posljednji sud, Madrid, Biblioteca Nacional Espana, Ms Vit. 14.2, f. 251. 


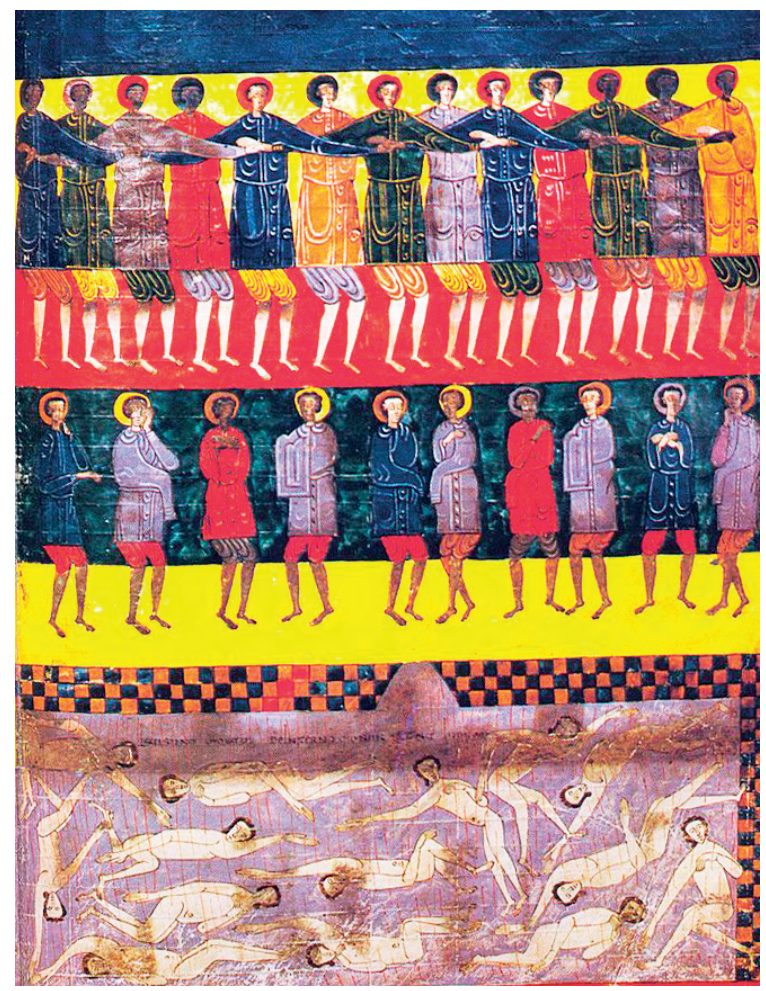

S1. 7.

Očito je da ona kola iznad te vizije pakla ilustriraju rajske prostore. Dva kola djevojaka, iz XIV. st., koje je naslikao Andrea Buonaiuto u bazilici Santa Maria Novella (Sl. 8) sastavni su dio zidne alegorije Put spasa, pa se njihovo značenje oblikuje upravo u tom značenjskom kontekstu.

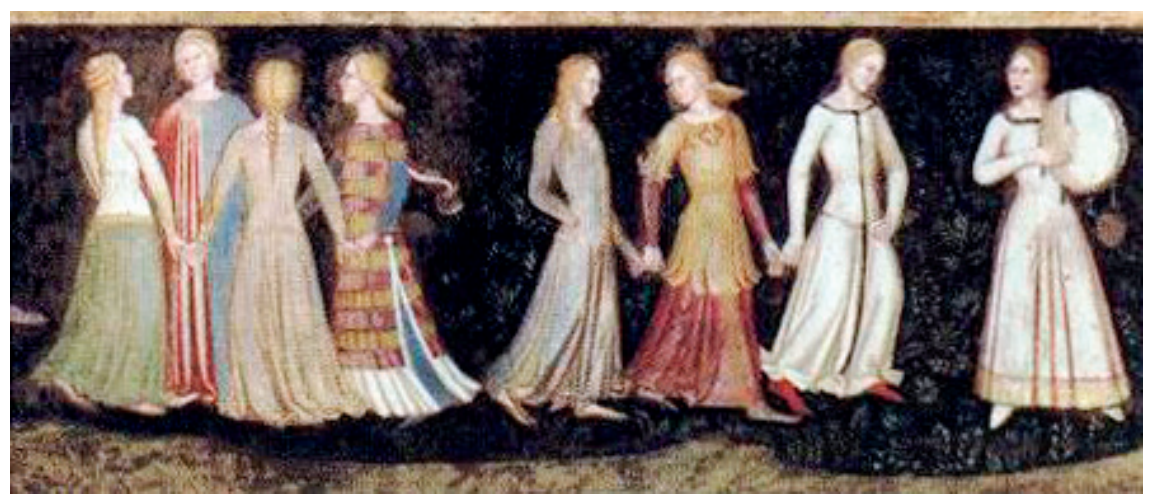

Sl. 8. 
U vrijeme kada se motiv kola intenzivno pojavljuje na stećcima južnoga pojasa, dakle tijekom prve polovice XV. st., slïka Fra Angeliko svoje anđeosko kolo (Sl. 9) u kompoziciji Posljednjega suda i Giovanni di Paolo svoju kompoziciju pet anđela koji plešu (Sl. 10). I jedan i drugi autor motivom kola predočavali su kršćansku viziju rajskoga blaženstva.

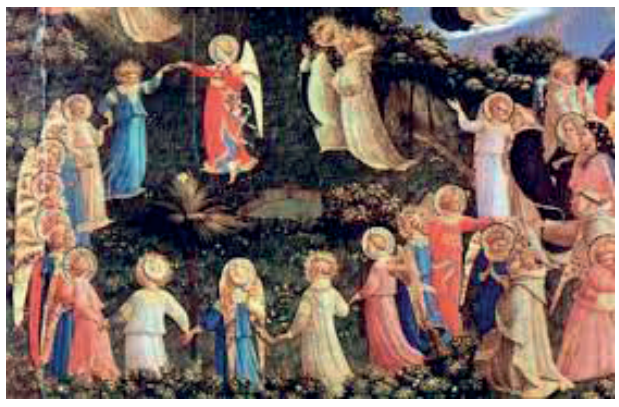

S1. 9.

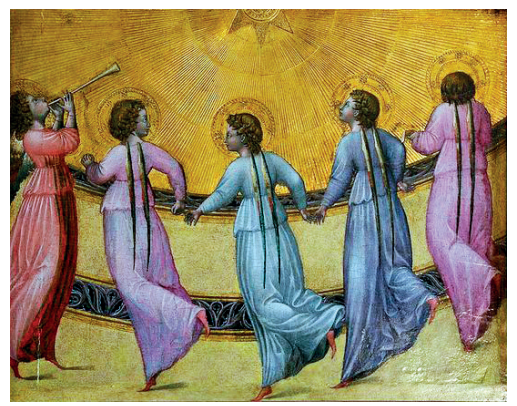

S1. 10.

I u rukopisima duhovnoga i pobožnoga sadržaja zapadne, prvenstveno gotičke minijaturne stilizacije susreću se naslikani plesni prizori. Tako u Psaltiru kraljice Marije, ${ }^{8}$ nazvanom po njegovoj prvoj poznatoj vlasnici, nekoliko se ilustracija dade interpretirati kolom ili korom (Sl. 11 i 12). Jedna od njih prikazuje kolo djevičanskih svetica koje plešu uz pratnju anđeoske lutnje, a drugu s četiri mladića koji se drže za ruke u laganom plesnom pokretu prate dvojica trubača.

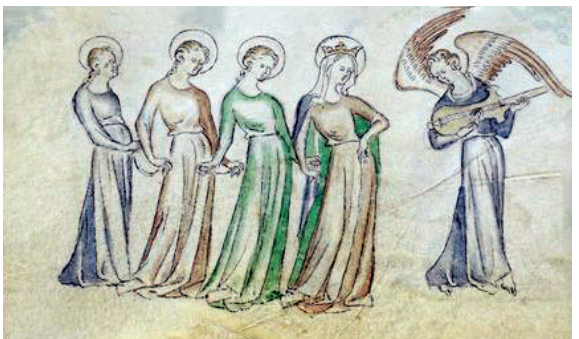

S1. 11.

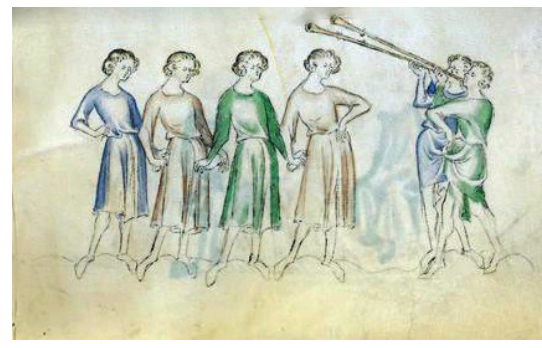

S1. 12.

Oba prizora vrlo slične kompozicije naslikao je darovit i nepoznat majstor iz XIV. st. kao i druge minijature slične provenijencije, ali je razlika u pojedinostima. Plesači nemaju aureole, ni muzikanti anđe-

8 Psaltir kraljice Marije (The Queen Mary Psalter), Royal MS 2 B VII, f. 201r; f. 229r. 
oska krila kao plesačice i njihov glazbeni pratilac. Stoga se njihovo značenje ne može jasno odrediti, premda im kontekst pobožnih pjesama osigurava duhovnu protežnost.

Posve je razumljivo da u svim navedenim primjerima likovni motiv kola oblikuje svoje značenje, odnosno ulogu znaka, u čvrstoj vezi s osnovnom idejom cjeline u kojoj se nalazi. Profani kontekst nesumnjivo naglašava u tom motivu profano značenje, a religijski, u ovom slučaju kršćanski kontekst, sanktificira tu profanu osnovu i pridaje joj odgovarajući simbolički i ezoterični smisao. Srednjovjekovna kultura smrti nije imala samo jasan kršćanski predznak, nego je sve u vezi s njom bilo prožeto kršćanskim svjetonazorom. Čak i stari pretkršćanski elementi, ukoliko su preostali, bili su posve kristijanizirani i odvijali su se u duhu eshatološkoga pogleda na vječnost, posebno oni koji se javno manifestiraju. Stoga ne djeluje dovoljno uvjerljivo interpretirati predstave kola na kasnosrednjovjekovnim spomenicima kao profanu pojavnost.

Na kapitelima francuskih (Sl. 13) i sjevernotalijanskih romaničkih crkava mogu se vidjeti reljefne predstave koje se doimaju kao kola. U središnjoj lađi Svetoga Mihovila (San Michele) u Cremoni jedna je takva skulptura (Sl. 14). Među sačuvanim romaničkim kapitelima iz stare opatijske crkve sv. Andrije od otoka u Brindisiju jedan je isklesan s desetak ljudskih figura koje se drže za ruke oblikujući klasičnu predstavu kružnoga kola (Sl. 15), čiji plesači gledaju prema vani. Takav plesni performans može se vidjeti jasno i na kasnijim likovnim prikazima u rukopisnim kodeksima, ali i na našim kasnosrednjovjekovnim spomenicima.

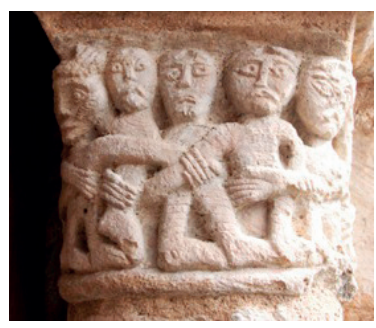

S1. 13.

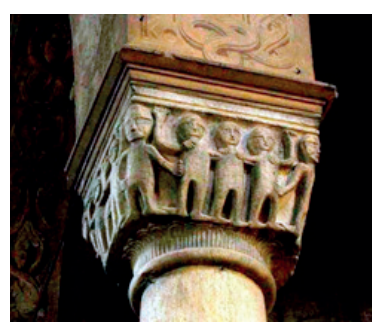

S1. 14.

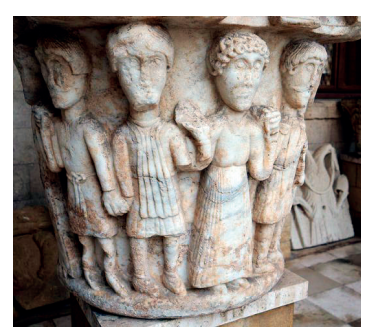

S1. 15.

Ta skulptura iz X. st. po svojoj je figuralnoj zamisli bliska stećku na manjoj nekropoli $\mathrm{Na}$ Mašete na obroncima Kamešnice iznad Voštana kod Trilja, na čijim je bočnim plohama isklesano u dubokom reljefu kolo od desetak plesača. Vjetrovi i zime izgladili su tu planinsku nadgrobnu skulpturu pa se na njoj ne daju prepoznati bilo kakvi 
tragovi individualizacije likova, ali je posve izvjesno da je zatvoreno kolo, kao i na brindizijskom kapitelu, okrenuto prema vani. Dakako, suvišno je i spominjati da su bilo kakve činjenične poveznice moguće između ta dva reljefna prikaza na podatnoj mramornoj podlozi i nepredvidivoj krečnjačkoj četvorini, koje dijeli najmanje četiri stoljeća, osim romaničkoga imaginarija na koji se oslanjao i majstor stećka s Kamešnice. On ili njegov učenik klesao je nadgrobni spomenik s istim motivom i rasporedom plesača u duvanjskom Prisoju na Steljcima, pa se ta dva uratka dozivaju i nadopunjuju. Svakako je važno da spomenik u Prisoju iznad prizora kola na sve četiri bočne strane, na gornjoj ravnoj plohi ima isklesanu reljefnu svastiku (Sl. 16), iskonski sunčani piktogram i starokršćanski oblik križa, pa se njegova predstava u toj kompoziciji doživljava kao središte kola, dajući mu astralno, odnosno nebesko značenje.

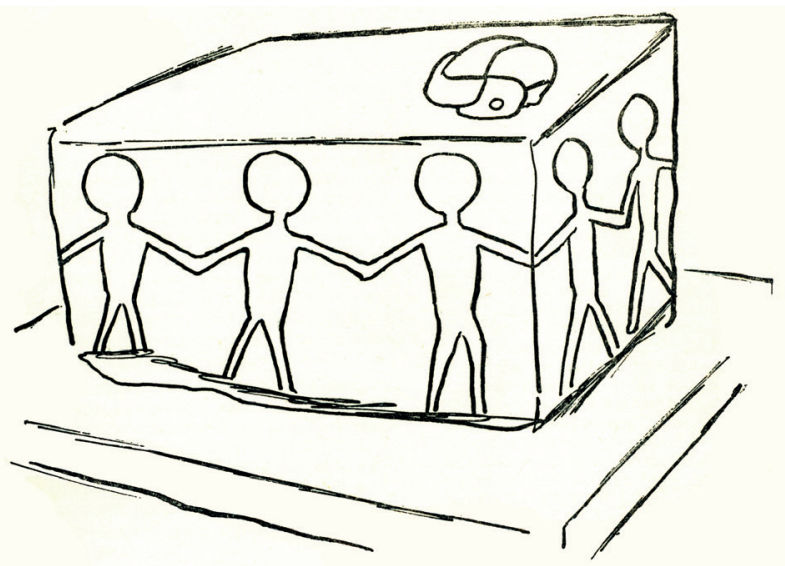

S1. 16 .

U cijelom srednjem vijeku postoji naglašen moralistički odnos prema kolu kao vidu društvene zabave. Ocjene se temelje na stajalištima ranih kršćanskih učitelja prema kojima je središte kola sam sotona. Melius fodere et arare, quam choreas ducere (Bolje kopati i orati nego kolo voditi!). Izricane su zabrane, objavljivane naredbe na raznim mjestima, a za klerike sub poena suspensionis! Možda su se ta moralno-kršćanska gledišta na životnu praksu izrazito nepovoljno odrazila na likovnu obradu toga motiva diljem Europe. Stoga iznenađuje učestalost, čak dominantnost toga motiva u popisu reljefnih ukrasa na kamenim nadgrobnim spomenicima iz XIV. i XV. st. u neposrednom jadranskom zaleđu od Cetine preko cijele Hercegovine, pred vratima trebinjskoga, dubrovačkoga, stonskoga i splitskoga biskupa. 
Ta rigorozna moralna poimanja plesa također su tema srednjovjekovnih minijaturista. U takozvanom Franjevačkom misalu, ${ }^{9}$ bogato oslikanom tijekom XIV. st., duhovito je prikazano kolo s moralističkom kršćanskom protežnošću (Sl. 17). Naime, sam Krist prati plesače pokazujući prstom na djevojku koja je malo podigla svoju dugu haljinu.

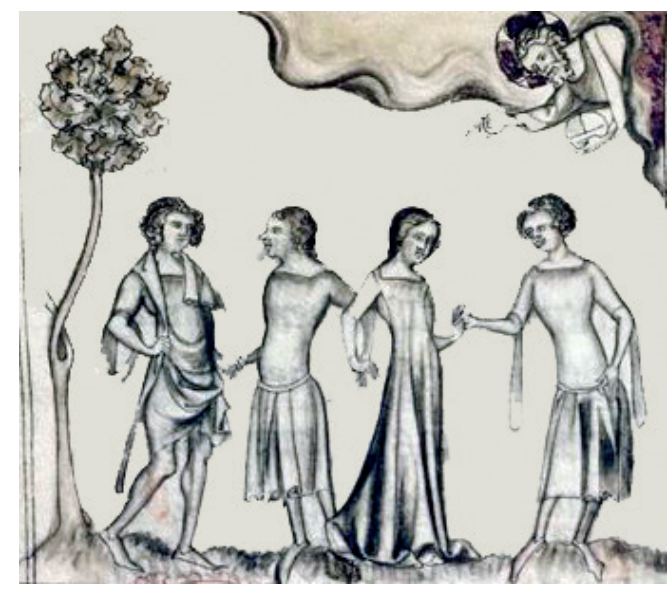

S1. 17.

U Brevijaru ljubavi,${ }^{10}$ moralističkoj zbirci tekstova koju je napisao franjevac i trubadur Matfre Ermengau prikazano je kolo (Sl. 18) koje vodi đavao uz trubačku pratnju njegovih paklenih drugova.

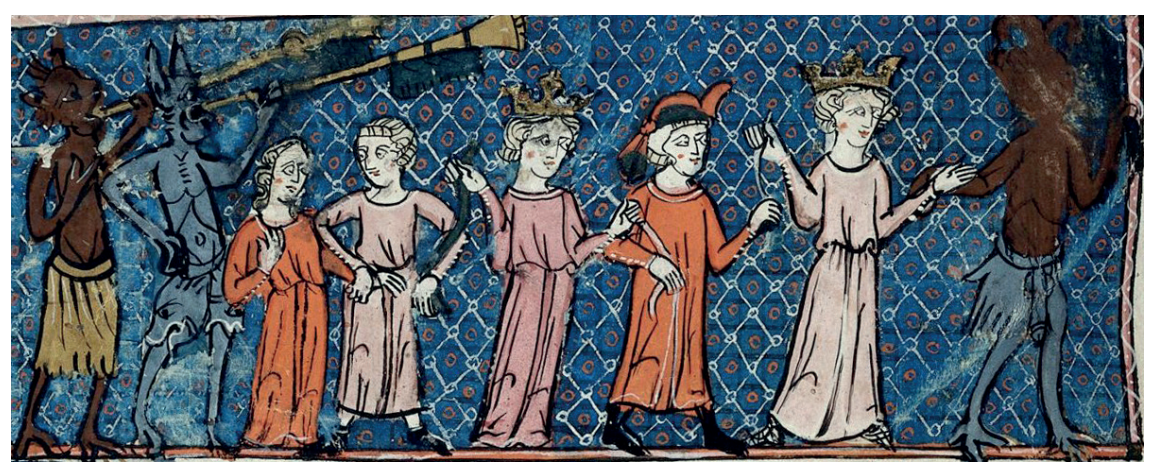

S1. 18.

9 Franjevački misal, Oxford, Bodleian Library, MS Douce 313, fol. 164v.

10 Brevijar ljubavi, (Breviari d'Amor), British Library, Royal 19 C I, fol. 204v. 
Nesumnjivo je da se takvo kritičko stajalište odnosi na suviše slobodne izvedbe plesa u srednjem vijeku, na stvarne performanse koji su u nekim slučajevima održavali veze s poganskim plesnim performansima. Međutim, postoje i posve drugačija, svakako kršćanskosimbolična poimanja, koja navode da makar neke kompozicije na stećcima ne shvate mimetički, nego simbolično. Zapravo, dovoljan je samo jedan citat iz Honorijeve Gemma animae, koji se i referira na bit funeralnih obreda: "Dva kora (kola) onih koji pjevaju psalme označavaju anđele i duhove pravednika, koji hvale Gospodina skoro uzajamnim glasom. Ograde u kojima stoje označavaju mnoge stanove u kući Gospodnjoj (Iv 14). Što ponekad iz kora, odnosno kola s procesijom k nekom oltaru idu i ondje pjevaju stojeći, označava duše koje odlaze iz ovoga života, Kristu pristižu i u društvu anđela Bogu zajedno pjevaju." (Duo chori psallentium designant angelos, et spiritus justorum, quasi reciproca voce Dominum laudantium. Cancelli in quibus stant, multas mansiones in domo Patris (Joan. XIV) designant. Quod aliquando de choro cum processione ad aliquod altare vadunt, et ibi in statione canunt, significat quod animae de hac vita euntes, ad Christum perveniunt, et in consortio angelorum Deo concinunt). ${ }^{11}$ Čini se da brojni stećci s prizorom plesača sugeriraju po svemu prije na tu kršćansku osnovu, a time, posve logično, i na misao da likovne obrasce tih ukrasa nisu improvizirali neuki kovači i klesari, nego u kršćanskoj likovnosti obrazovane osobe.

\section{Metodološko polazište}

Interpretiranje likovnih prizora na stećcima iz perspektive još uvijek aktualne teorije odraza, rigidnoga pozitivističkog prežitka, kao registriranje prizora iz svakodnevnoga života gdje pripada i onaj općeprihvaćeni zaključak o posmrtnom kolu. Upravo zahvaljujući motivu kola, posebice u kombinacijama s prizorima dvoboja, stvoreno je najstarije pučko objašnjenje tih likovnih kompozicija i samih stećaka kao mjesta tragičnoga sukoba svatova koji su se pobili jer se jedni drugima nisu htjeli skloniti s puta ili su išli po istu djevojku, pa su izginuli i na tom mjestu pokopani. Stoga se za brojne nekropole govorilo da su to svatovska groblja. Tako se i za dvije odvojene skupine stećaka Na Mašete iznad Voštana (Kamešnica) pričalo da su groblja sukobljenih svatova, na Gorici kod Stoca i na drugim mjestima. ${ }^{12} \mathrm{Ta}$

11 Honorius Augustodiensis, Gemma animae, Patrologia Latina, 172, 588.

12 Ante ŠKobalj, Obredne gomile, Sveti Križ na Čiovu, 1970., str. 315. 
predaja, potaknuta upravo reljefnim prikazima kola, etnološkim činjenicama i davnim valjanim etičkim normama u obraćanju na javnome mjestu, ima u sebi više sustavnosti i privlačnosti od spomenute teorije odraza, osobito zato što polaze od likovne kompozicije kao semantičke činjenice koja upućuje na nešto drugo. Zapravo ta folklorna interpretacija, bez obzira na njezinu narav domišljene predaje, podrazumijeva motiv kola na stećcima indeksnim znakom, kao što ga teorija odraza podrazumijeva ikoničnim. Ostaje još treća mogućnost interpretacije da je to simbolički znak, odnosno nebesko ili anđeosko kolo, kako sugerira Marian Wenzel uz nekoliko spomenika i tvrdi Ante Škobalj. Izvan tih mogućnosti ne može se govoriti o znaku, ali može o pukoj dekoraciji i ispunjavanju praznoga prostora plohe frizovima koji u izvornom smislu nemaju strukturu znaka. Dakle, ako je kolo na spomeniku u izvornom smislu bilo ikonički ili simbolički znak, onda je bilo moguće da tom označitelju isklizne ili se jednostavno zaboravi njegovo označeno. U tom slučaju nastaje metamorfoza u kojoj sam piktogram nadomješta ispražnjenu ljušturu smisla pretvarajući indeksni, odnosno simbolični znak u ikonički, prema kome kolo označava, kako hoće sljedbenici teorije odraza, kolo iz svakodnevnoga života pokojnika. Međutim, na stećcima postoje kompozicije s kolom u kojima pojedini likovni elementi otklanjaju spomenutu ikoničku odrednicu i podupiru simboličku vrijednost znaka, makar u izvornoj crtačevoj zamisli. U svjetlu toga semiološkog pristupa sve one podudarnosti etnološke naravi nisu interpretirale značenje, nego samo stilizaciju označitelja, njegovu piktogramsku protežnost. Iz te perspektive nije uvijek bitan broj plesača, koji često diktira veličina kamene plohe ili klesarov izbor, niti je važno je li razigrano ili statično, ide li na jednu i drugu stranu. Nisu ni podjele na muške i ženske igrače uvijek točne, niti mogu dekodirati poruku.

\section{Kolo i križ}

Jedan od sljemenjaka s Piska iz Budimira, ukrašen reljefnim prikazima na svim bočnim plohama, jasan je primjerak izvornoga likovnog nadahnuća (Sl. 19). Na njegovu zapadnom pročelju ispod dominantne svastike, staroga sunčanog simbola i ranokršćanske inačice križa, koja zauzima središte gornjega dijela plohe s trokutastim zabatom, tri su figure koje se drže za ruke. U sredini je figura u dugoj haljini, a njezini bočni pratioci s ispruženim slobodnim rukama drže za ruke iste takve figure prikazane na bočnim stranama spomenika, na jednoj pet a na drugoj četiri silute igrača, pa svi zajedno predstavljaju 
jedinstveno kolo od dvanaest figura, a prelomljeno na tri plohe spomenika. Na južnoj bočnoj plohi ispod opisane kompozicije uklesan je još jedan red igrača u istom položaju, čiji broj nije moguće odrediti zbog oštećenosti spomenika. Možda se radi o četiri figure, kako ih prikazuje M. Wenzel. ${ }^{13}$ Također, sa sjeverne bočne strane ispod prvoga igrača jedna je samostalna figura s uzdignutim rukama, koje su produžene i zašiljene na krajevima, pa se može pomišljati da su to zapravo predmeti koje taj lik podiže u svojoj egzaltiranoj zaigranosti.
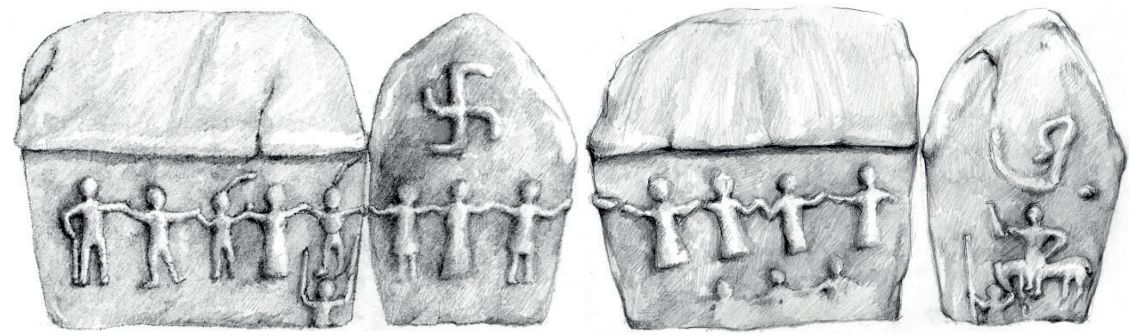

S1. 19.

Reljef je od atmosferilija istrošen da bi se uočila bilo kakva nijansa ili prijelaz. Dakle, ta jedinstvena i na tri plohe prelomljena kompozicija ima sedamnaestak ljudskih figura u igri, što dovodi u pitanje vjerodostojnost poznatih statistika o broju figura u predstavama kola na stećcima, koje su se zasnivale na prikazivanju stanja samo na jednoj plohi. Prelamanje jedinstvene kompozicije kola na više ploha spomenika može se naći i na drugim nekropoloma. Možda je najsličnija takva predstava kola, daleko bolje očuvana, s malo poznate nekropole iz Hodova kod Stoca (Sl. 20) na kojoj je kolo prelomljeno na zapadno pročelje od tri figure, $s$ istim mješovitim rasporedom kao u Budimi-
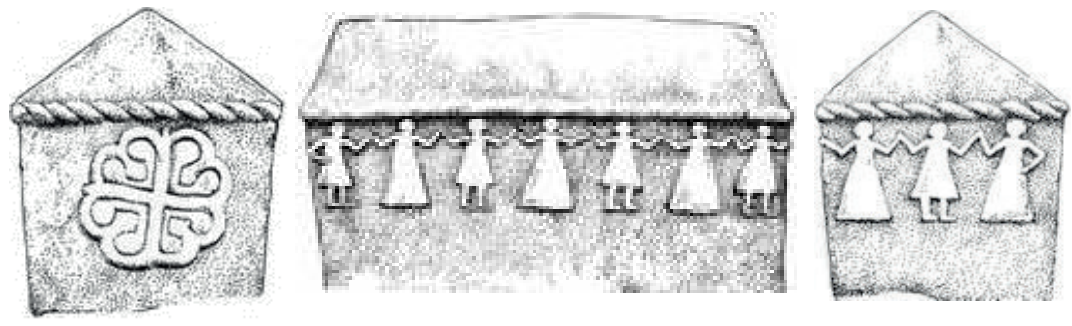

S1. 20.

13 Marian Wenzel, Ukrasni motivi na stećcima, XCV., br. 2. 
rima, i na sjevernu plohu sa sedam plesača koji dopiru do cvjetnoga istostraničnoga križa na istočnom začelju. ${ }^{14}$

$\mathrm{Na}$ Voštanima je uostalom kolo od deset figura uklesano i raspoređeno razlomljeno na sve četiri strane jednoga sanduka, do sada neprimijećenog. Primjera ima još od Duvna do stolačkih nekropola, međutim, posve je dovoljan taj budimirski primjerak koji garantira da je njegovom konačnom ukrašavanju prethodila jedinstvena kompozicija u jednoj ravni.

Na uskoj plohi začelja prikazan je vitez konjanik s uzdignutom desnicom i ljevicom, savijenom na boku, dok mu koplje i konja za uzde pridržava pješak. Iznad konjanika je uklesana nejasna pojedinost koju je teže identificirati. U sličnim predstavama na drugim stećcima ponekada je tu usječen lik mladoga mjeseca. Sama za sebe ta kompozicija podsjeća snažno na slične kompozicije u srednjovjekovnim rukopisnim kodeksima gdje redovito predstavlja cjelovit portret naručioca, odnosno vlasnika knjige. Međutim, u kontekstu predstave s cijeloga spomenika konjanik bi mogao biti sam pokojnik koji je krenuo na posljednje putovanje. On je okrenut prema kolu ispod sunčanoga križa s odloženim kopljem i uzdignutom rukom pozdravlja one koji ga s veseljem sačekuju.

\section{In paradisum deducant te angeli}

Analizira li se prizor onoga kola od sedamnaest sudionika, prelomljenoga na tri strane budimirskoga stećka u kontekstu sličnih kompozicija, primijetit će se da je njegov nukleus trijada s pročelja iznad koje stoji križ u obliku svastike, što svojim i kršćanskim i pretkršćanskim odrednicama sugerira prostore u kojima će duša pokojnika, kao na rimskim stelama iz istoga kraja, naći svoje konačno boravište. Na jednoj ploči s Ciste figure $\mathrm{u}$ istom rasporedu ispod jednostavnoga križa središnja su likovna kompozicija. Na jednom sljemenjaku u Hodovu kod Stoca na pročelju je također trijada koja prerasta na bočnoj strani u niz figura, a na začelju završava cvjetnim križem koji po tim elementima sugerira simboliku rajskih prostora. Na spomenicima s Poljanica iz Biska trijade se pojavljuju na bočnim stranama i predstavljaju osnovne likovne jedinice u reljefnoj kompoziciji (Sl. 21). Središnja figura s pročelja spomenika s križem u ruci,

14 Miroslav Palameta, "Stećak za Peru Marijanovića", u: Stolačko kulturno proljeće, Godišnjak za povijest i kulturu, IX., Stolac, 2011., str. 73-77. 
koja predstavlja po tom atributu nekoga od svetaca, s križem također isklesanim na začelju, otklanja profanost kola i kristijanizira ga u potpunom smislu.
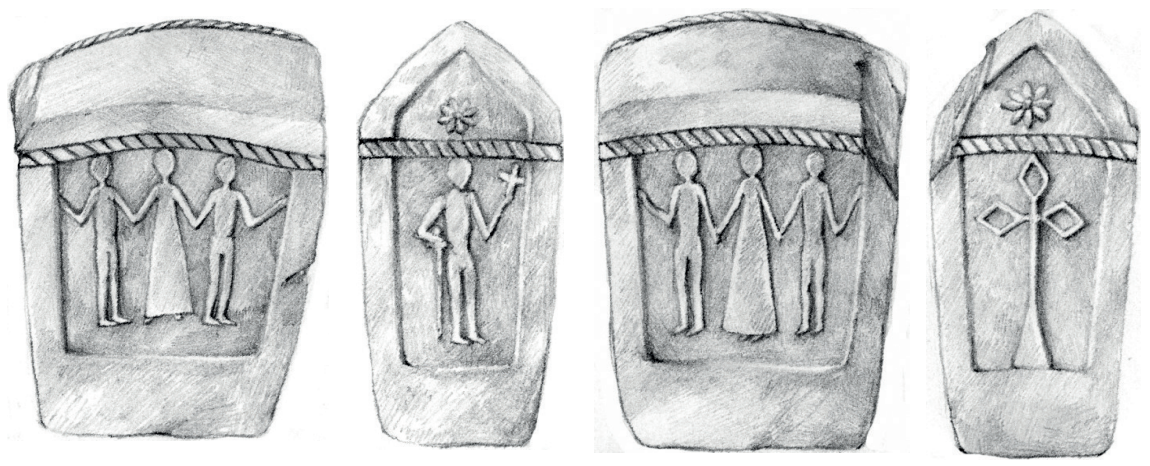

S1. 21.

Pogledaju li se još jednom kompozicije tih elegantnih likova na stećcima s Poljanica iz Biska, vidjet će se da na druga dva spomenika pratioci središnje figure pridržavaju atribute uzvišenoga. Desni je pratilac u oba slučaja s mačem, a lijevi jednom s ljiljanom (Sl. 22), a drugi put s grančicom palme (Sl. 23). ${ }^{15}$ Lik s palmom pojavljuje se na istom stećku u dvije različite stilizacije. Jednom je to cijela palmina grana, a na suprotnoj strani vitez sa štitom i mačem drži u ljevici modeliranu palminu mladicu (Sl. 24) koju nose kršćanski mučenici gotičke stilizacije, kao oni na portalu sv. Ciriaka u Anconi.

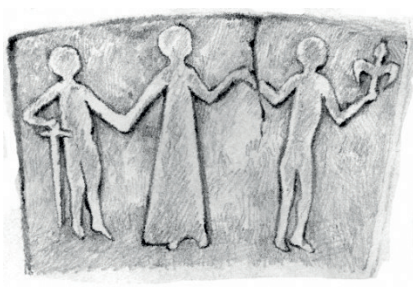

S1. 22.

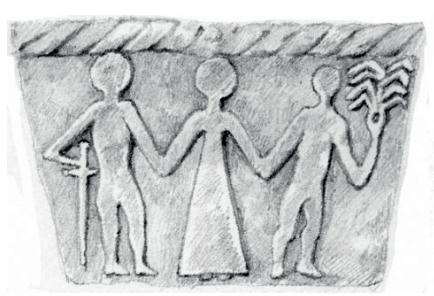

S1. 23.

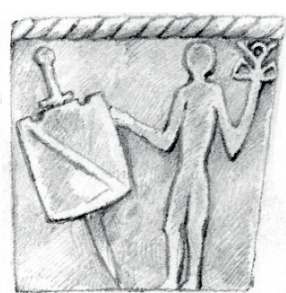

S1. 24.

15 Ante Milošević, Stećci i Vlasi, Stećci i vlaške migracije 14. i 15. stoljeća u Dalmaciji i jugozapadnoj Bosni, Regionalni Zavod za zaštitu spomenika kulture, Split, 1991., str. 18-47. 
Stilizirani ljiljani i križevi u samostalnom položaju na tim spomenicima samo potkrjepljuju kršćanski identitet likova, koji se daju prepoznavati kao djevci i djevice, anđeli i mučenici.

Očito je da ti isklesani prizori nisu nadahnuti razbludnim i nepristojnim igrama koje osuđuju srednjovjekovni propovjednici, niti ilustriraju prizore iz svakodnevnoga života pokojnika. U svim tim spomenutim izvedbama prije bi se moglo uočavati ispravnost Škobaljeve interpretacije. Takvo naslućivanje na osnovi dijelom sačuvana semantičkoga konteksta može usmjeriti ezetorijski misao da se trijadu s pročelja kao polaznu cjelinu sagleda kao ilustraciju onih riječi pogrebnoga obreda: $U$ raj odveli te andeli i pri tvom dolasku primili te mučenici (In paradisum deducant te angeli, in tuo adventu suscipiant te martyres), a cijelu kompoziciju kao nastavak toga teksta u kojoj se spominju mučenici i sveci nebeski.

\section{Crux triunfans}

Slična predstava koja se također iščitava kao kolo, premda nema nikakvo etnološko uporište, isklesana je na sjevernoj bočnoj strani sljemenjaka iznad Voštana (S1. 25). Četiri siluete koje u rukama drže uzdignute križeve i jednu palmu ili buket cvijeća radio je isti klesar kao i susjedni spomenik s kolovođom i tri igračice, koji je upravo interpretiran.
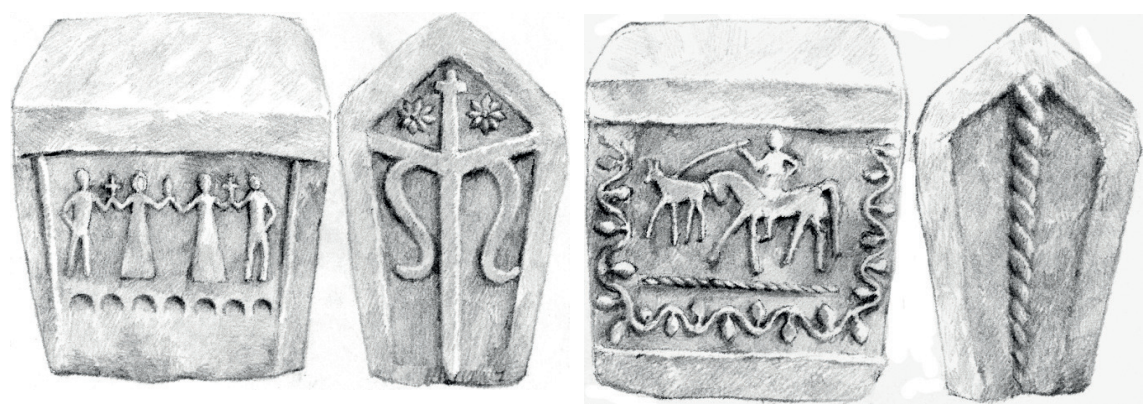

S1. 25.

Ta kompozicija posve jasno pokazuje da se u njezinoj osnovi pojavljuje dva puta ponovljen isti prizor, koji je klesar imao u svome repertoaru. Radi se o motivu križa kao pobjedničkoga znaka (crux triunfans) kojega uzdižu ili podržavaju sa strane dvije ljudske figure, a pojavljuje se na nekoliko kasnosrednjovjekovnih spomenika u različitim stilizacijama. Najbliži je spomenik s tom temom iz Grebnika u Zabiokov- 
lju (sl. 26), a najizvornija inačica Grubačev je rad iz Opličića (sl. 27), na kome dvije siluete ljudskih figura u dugim haljinama uzdižu križ. Predstava iz Rilića kod Kupresa (sl. 28), predstavljala bi prelomnicu u razvoju toga motiva u kome se križ odvaja od dviju figura pa one egzistiraju samostalno kao par, često kao muškarac i žena.

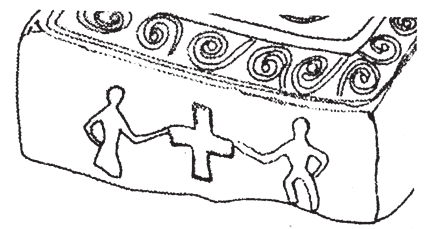

Sl. 26.

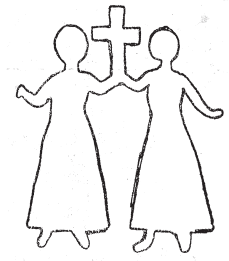

S1. 27.

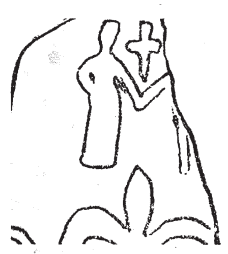

S1. 28.

Dva spomenika s Grebnika kod Slivna u Zabiokovlju, koje je radila ista ruka, pokazuju kako je od dviju figura s križem (Sl. 29) nastala kompozicija kola s križem (Sl. 30). ${ }^{16}$

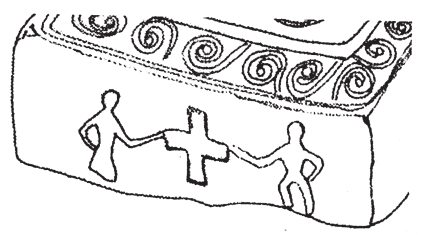

S1. 29.

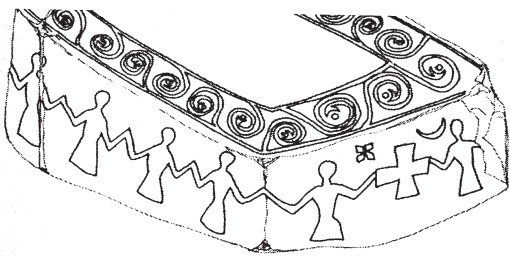

S1. 30.

Izvorno nadahnuće iz ranosrednjovjekovne likovne umjetnosti jasno se prepoznaje na ravenitanskim mozaicima u crkvi San Vitale (Sl. 31), na uništenim reljefima kamenih baza visokih stubova iz Carigrada od kojih su ostali samo crteži koji se čuvaju u Cambridgeu ili izrezbareni na koricama od slonovače, u kojima su bili uvezani srednjovjekovni kršćanski rukopisi iz Armenije i Rusije, na kojima dva anđela u položaju lebdjenja pridržavaju medaljon s križem. ${ }^{17}$ Postoje i

16 Ljubomir Gudelj - Marijan Lozo, "Arheološki spomenici u Krstacima i Slivnu", u: Zavičajno blago u funkciji razvoja Zabiokovlja, Književni krug, Split, 2005., str. 113.

17 Andrè Graber, Le vie della creazione nell'iconografia cristiana. Antichità e Medioevo, Jaca Book, Milano, 1988., sl. 37, 57, 76, 86. 
reljefni prizori u kojima anđeli stoje i pridržavaju medaljon s križem. Fotografiju jedne takve kompozicije iz Armenije s kraljem Gagikom I. donosi i knjiga The Glory of Byzantium. ${ }^{18}$ Prema tome, likovi s triljskoga spomenika nisu igračice, nego udvostručena kompozicija s anđelima, koja se na ravni znaka prepoznaje kao prikaz kola.

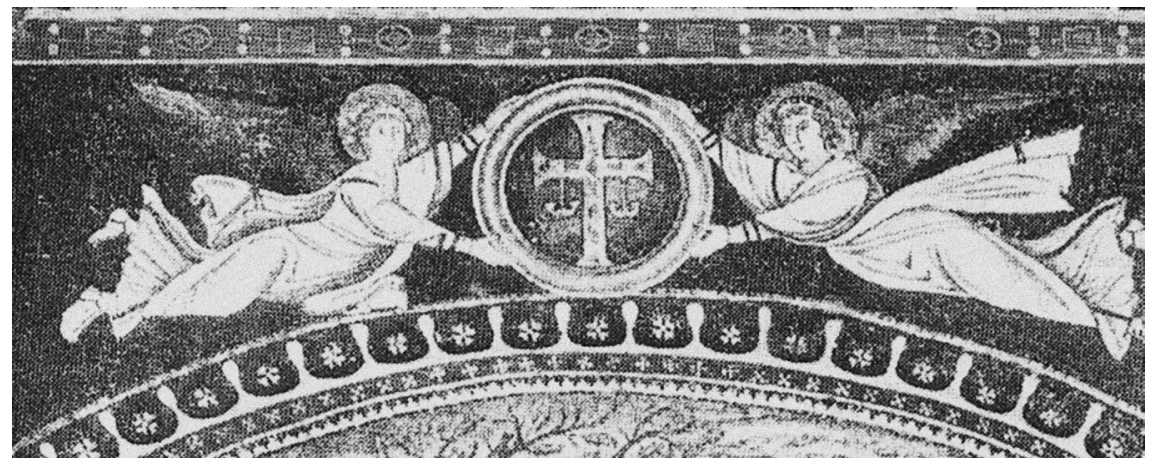

S1. 31.

Prema tim odnosima dvije figure koje drže križ bili bi zapravo anđeli. Spomenuti stećci iz Zabiokovlja jasno pokazuju kako je od dviju figura koje drže križ postalo na drugom stećku kolo: isti klesar koji je na jednom pročelju imitirao izvornu kompoziciju, na drugom je duž ostalih ploha dodavao likove igrača, odnosno anđela kako bi ispunio prostor.

$\mathrm{U}$ tu skupinu prizora sa stećaka $\mathrm{s}$ istim osnovnim značenjem moglo bi se uvrstiti i nekoliko kompozicija s mostarskih nekropola. Na onoj u Troskotima kod Mostara, poznatoj samo po spomeniku Ljupka Vl(a)snića, i na onoj u Gornjem Pologu, posve nepoznatoj široj znanstvenoj javnosti, pojavljuje se kompozicija od nekoliko ljudskih silueta u nizu, od kojih dvije među sobom drže veliki mač, okrenute oštrice prema dolje. $\mathrm{Na}$ tri spomenika različitih oblika ta je kompozicija klesana u dubljem reljefu s istim tipom mača i nejednakim brojem figura. Svi dosadašnji istraživači bez dvojbe bi te reljefe interpretirali kolom. Nedvojbeno ga je radio lokalni majstor, jer je takva predstava nepoznata na ostalim nekropolama.

Najljepši od njih i najbolje očuvan visoki je sanduk s Troskota, s kojim bi se najjednostavnije interpretirala ta lokalna i do sada jedva

18 Helen C. Evans - William D. Wixom (ur.), The Glory of Byzantium: Art and Culture of the Middle Byzantine Era, A.D. 843-1261, Metropolitan Museum of Art, New York, 1997., str. 353. 
poznata predstava (Sl. 32). Na njegovu zapadnom pročelju dvije shematizirane figure s uzdignutim rukama drže mač koji nadmašuje njihovu visinu, zauzimajući cijelu širinu kamena plohe. S obje bočne strane spomenika isklesane su paralelno još po četiri siluete, a na začelju još dvije. Cijela kompozicija od dvanaest figura u dugim halinama postavljena je kao friz ispod gornjega ruba, pa zbog dugoga mača koji svojom oštricom premašuje zamišljenu donju crtu kretanja stvara dojam lebdjenja. Spomenuta pozicija upravo maču daje najvažnije mjesto u cjelokupnu prizoru, postavljajući ga na ono mjesto gdje se obično uklesava križ ili njegova supstitucija.

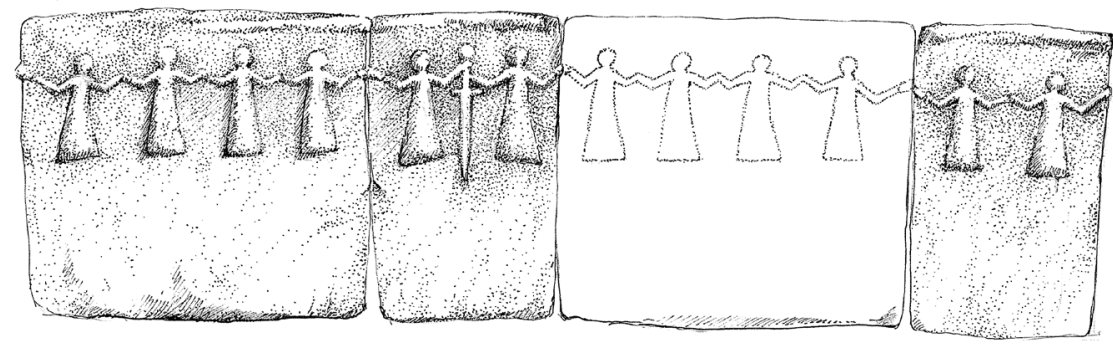

S1. 32.

Svojom bogatom simbolikom mač ima ambivalentna značenja. Upravo tako postavljen s oštricom i uzdignutom križnicom, on i vizualno sugerira križ. U srednjem vijeku smatralo se da je mač odlomak križa svjetlosti ${ }^{19}$ Posve je izvjesno kako na tim spomenicima mač u spomenutoj poziciji zamjenjuje križ. Središnja predstava mača s dvije ljudske figure koje ga drže osnovni je znak, a ostale su figure samo dodatak, klesarev osobni doprinos kojim je u formi kola ukrasio cijeli spomenik.

\section{Kolo i dvoboj}

Da se predstava kola na stećcima nije klesala kao ikonički znak upućuje jasno jedan od spomenika u Boljunima na kome niz od šest ljudskih silueta u dugim haljinama predvodi jahač na jelenu (Sl. 33). Bilo bi teško pretpostaviti, naime, da ta scena "ilustrira prizore iz svakodnevnoga života pokojnika". Nikakva etnološka tradicija takvu vezu

19 Jean Chevalier - Alain Gheerbrant, Rječnik simbola, Nakladni zavod Matice hrvatske, Zagreb, 1983., str. 373. 
ne bi mogla potvrditi. Postavlja se logično pitanje je li to uopće kolo ili nešto drugo? Ta lokalna inačica koja je potaknula sličan prikaz na obližnjim nekropolama s Toplice i s Nekuka kod Stoca, kao označitelj upozorava svojim izgledom na neki za nas skriveni i utonuli smisao koji je sceni osiguravao vrijednost simboličkoga znaka. Za njegovu rekonstrukciju postoji samo likovna triptihalna kompozicija prelomljena na sve četiri strane niskoga boljunskog sanduka, pa interpretatoru ne bi pomoglo ni kada bi bio siguran kreće li se to "kolo" naoposun ili naopako, na čemu su inzistirali brojni znalci i sljedbenici etnoloških rješenja.
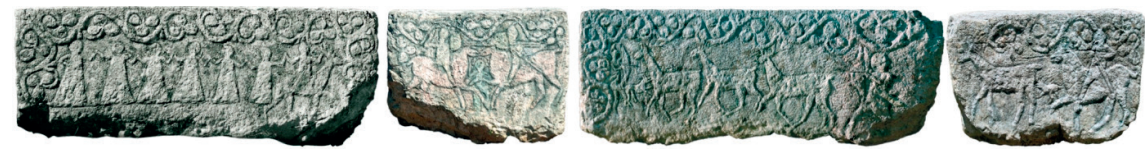

S1. 33.

Zapravo, do sada nije nitko ni primijetio da je taj prikaz dio spomenute kompozicije u čijem središtu na zapadnoj čeonoj plohi dominira reljefni prikaz psihomahije. ${ }^{20}$ Prema toj središnjoj predstavi orijentiraju se bočne scene. Sa sjeverne plohe spomenika usmjeren je jahač na jelenu sa šest likova koji se drže za ruke, kao što se sa začelja kreće konjanik koji kopljem progoni jelena, odnosno stado košuta $s$ jelenom s južnoga boka, uhvaćeno u zamku strijelaca. Te bočne scene tek s psihomahijom kao središtem zasnivaju svoj izvorni smisao. Jedino u tom odnosu bilo bi ga moguće naslutiti. Wenzel je tu scenu neobičnoga kola interpretirala iz perspektive simboličnoga značenja jelena kao psihopompa. Da je autorica nastavila svoju interpretaciju na tom tragu i uvažila svjetonazor pokojnika pod stećcima, koji je u XIV. i XV. st. mogao biti samo kršćanski, dekodirala bi nedvojbeno da je na toj reljefnoj plohi predstavljeno kolo nebesnika u koje će se pridružiti i duša pokojnika s boljunske Gulubače, nakon što je u žestokom moralnom dvoboju pobijedila izazove viteza zla i tamnosti.

20 Pojam psihomahije, koji je potaknuo moralistički ranokršćanski Prudentijev spjev o sukobu mana i vrlina, uzima se ovdje uvjetno jer nema nekoga drugog prikladnijeg termina koji bi mogao imenovati predstavu suprotstavljenih konjanika i njihov ezoterični smisao na nadgrobnim spomenicima. Sama likovna predstava pojavljuje se i u svjetovnoj i u sakralnoj umjetnosti srednjega vijeka, još prije pojave viteških turnira. Predstave su poznate i u našim krajevima s votivnih pločica iz rimskoga perioda sakralne srednjovjekovne umjetnosti. 
Prizor kola u kompozicijama u čijem je središtu scena dvoboja iščitava se također na sličan način u svakom pojedinačnom slučaju. Vrlo reprezentativan spomenik s takvim reljefom visoki je sanduk s Borja kod Klobuka (Sl. 34), prenesen sa svoga prirodnog i zadanog mjesta u vrt sarajevskoga Zemaljskog muzeja.
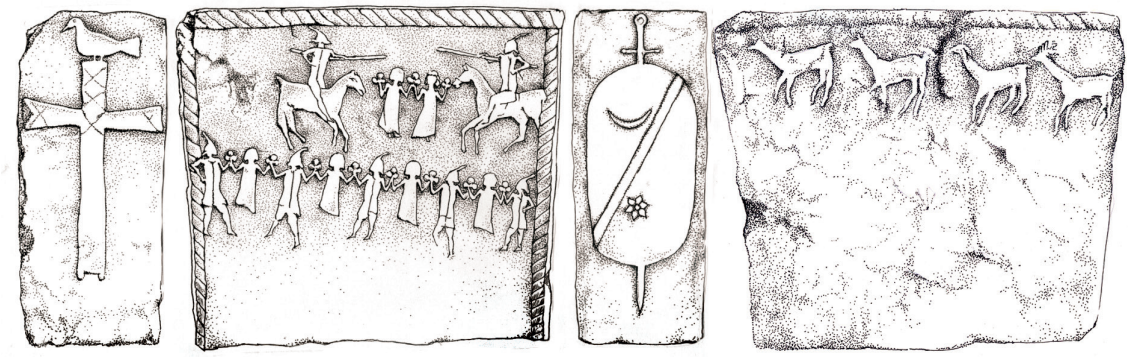

S1. 34 .

Stilizacija ljudskih figura, igrača i vitezova u maniru gotičkoga likovnog predstavljanja, pojačana dvorskim mi-parti kostimima pokazuje svoju likovnu provenijenciju iz svijeta gotičke tapiserije ili čak minijature. Ta scenografija također upućuje na neodvojivost motiva kola od središnje duelantske scene, makar na tom spomeniku. Plesači i plesačice, čak i one dvije dame među suprotstavljenim konjanicima drže u rukama križolike bukete ili cvjetne križeve čija bi sigurnija interpretacija upućivala na identitet likova. Amblematičnost predstava na užim bočnim stranama (križa s golubicom na pročelju, odnosno štita $s$ mačem na začelju), sugerira alegorijski smisao i toga, izrazito profanoga ceremonijalnog prikaza kola i dvoboja. Nepoznati autor likovnoga predloška sigurno je znao približan smisao takve scene. Međutim, to je značenje utonulo ili posve iskliznulo, pa ga današnji promatrač prema svojim mogućnostima pokušava rekonstruirati ili učitati.

Drugi spomenik sa sličnom kompozicijom iz Salakovca kod Mostara (Sl. 35), do sada nespominjan u stručnoj literaturi, s male i devastirane nekropole na seoskom raskrižju, posve je drugačije stiliziran. Likovni predložak njegove kompozicije, razlomljene na sve četiri bočne strane spomenika, radio je neobrazovan, ali talentiran crtač koji je na pročelju predvidio scenu dvoboja konjanika, a osamnaest plesača i plesačica rasporedio kao friz na tri ostale plohe. Kvadratni kameni blok rušilački je stroj pomaknuo sa zadanoga mjesta, preokrenuo ga, pa sada leži na svojoj gornjoj plohi s pokidanim glavama plesača. Crtač je usmjerio stopala ljudskih silueta u jednom pravcu, 
pa iz te perspektive duelantska scena prekida friz i izgleda naknadno montirana. Ipak, bez obzira na te nespretnosti slikara i klesara, jasna je povezanost kola i dvoboja u osnovnoj zamisli.

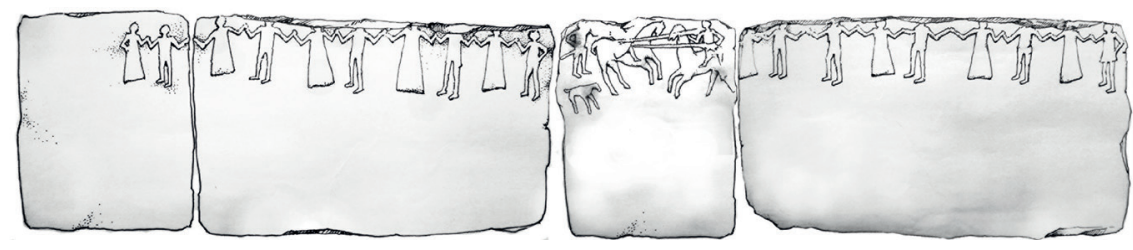

S1. 35 .

Dakako, takva predstava u svojoj shematiziranosti ne može biti nadahnuta bilo kakvim performansom iz stvarnoga života, pa bi se njihov smisao u toj kompoziciji, kao i u onoj na spomeniku s Borja dao naslutiti tek u jasnijem poimanju samoga dvoboja u sličnim prikazima čija je povijest daleko duža od pojave na kasnosrednjovjekovnim nadgrobnicima iz naših krajeva. Jasno, nema nikakva razloga da njihova uobičajena i općeprihvaćena interpretacija psihomahijom, borbom dobra i zla za dušu pokojnikovu u sferi srednjovjekovne likovne i literarne tradicije ne bude primjenjiva i na predstave sa stećaka. Naprotiv, u sferi posljednjih stvari svakoga čovjeka, na čijem je prvom mjestu smrt, u tim bi kompozicijama kolo moglo izražavati uvjerenje ili želju pa onda radost da je pokojnikova duša u posljednjem dvoboju bila na strani dobra i time osigurala rajsku ulaznicu.

Sličan ezoterijski smisao moglo bi imati kolo kao prateći element u kompozicijama lova na jelena, čija se učestalost posebno primjećuje u južnom dijelu središnjega prostora stećaka. Predstave kola koje se koncentriraju upravo oko toga prizora daju se na ravnini strukture i stilizacije povezivati istodobno sa sličnim prikazima lova u kasnosrednjovjekovnim minijaturama is odjekom kamene plastike na salonitanskim rimskim sarkofazima, kako je već ranije rečeno, ali se u ovom članku zbog njegove opsežnosti izostavljaju podrobnije analize pojedinih spomenika.

\section{Tri plesača i kolovođa}

Promatra li se s više pozornosti prizor kola s Mašeta u kojemu kolovođa predvodi tri ženske figure (Sl. 36), onda se ne mogu zanemariti spomenici s inačicama toga motiva, niti izbjeći interpretacija Marian Wenzel koja je ostavila mogućnost da se ta kompozicija može povezi- 
vati s reljefnim pločama s prikazom Silvana i triju menada. Kako su arheološka istraživanja potvrdila ilirski romanizirani kult tih jarećih i kozjih božanstava u starosjedilaca Cetinske krajine i susjednih područja, njezino referiranje u tom smjeru traži u ovom kontekstu jasnije određenje. ${ }^{21}$ Potaknuta sličnim sastavom strukturalnih elemenata i izgledom kompozicije, ona je toj tezi pridala suviše veliku važnost, a da nije odgovorila na ključno pitanje kako je izrazito poganski koncept prevladao petnaestostoljetni hijatus u kome je vladala samo kršćanska paradigma i pojavio se na kasnosrednjovjekovnim spomenicima.
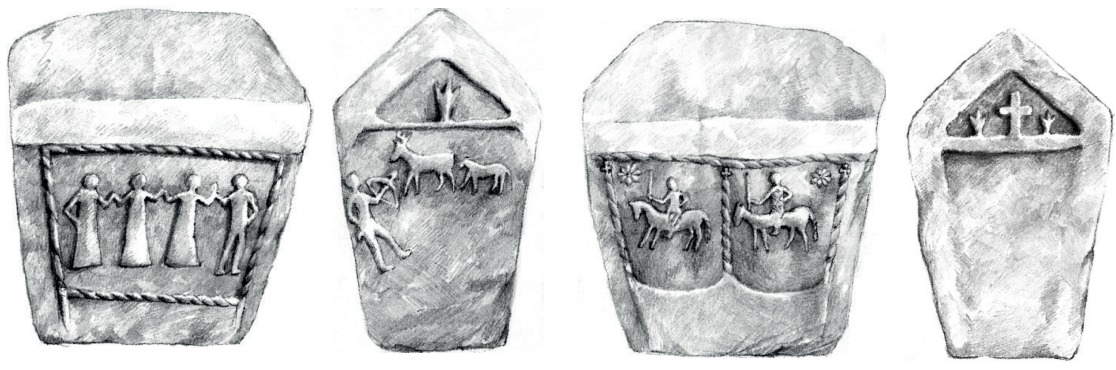

S1. 36 .

Zapravo nije ni teško odgovoriti u što su se likovne dionizijske i jareće kultne predstave diljem Mediterana preobličile u postupku kristijanizacije (Sl. 36). Autorica nije također odgovorila odakle u najkvalitetnijoj izvedbi te teme, u onoj sa spomenutog stećka s Ciste u kolovođe križ u lijevoj i palma u desnoj ruci. Te su pojedinosti važne isto koliko i broj figura u ovoj kompoziciji.

Taj oblik kola, odnosno znaka predstavljena kolom, pojavljuje se na još nekoliko nekropola. Uklesan je na nekoliko spomenika s Ciste, na jednom sljemenjaku iz Krvavice, koji je prenesen u vrt Franjevačkoga samostana u Makarskoj, na Dikovači kod Imotskog i dva puta na bočnim stranama sanduku Taraha Boljunovića iz Boljuni kod Stoca, koji je radio kovač Grubač. U svakom slučaju sve se te inačice razlikuju po nekoj pojedinosti, ovisno o tome koliko je samom kovaču bilo blisko izvorno nadahnuće ili simbolički smisao toga znaka. U tom smislu bila bi scena na sljemenjaku Jerka Kustražića s Ciste najbliža takvom nadahnuću i najpodatnija za interpretaciju (Sl. 37).

21 Marian Wenzel, Ukrasni motivi na stećcima, str. 348. 


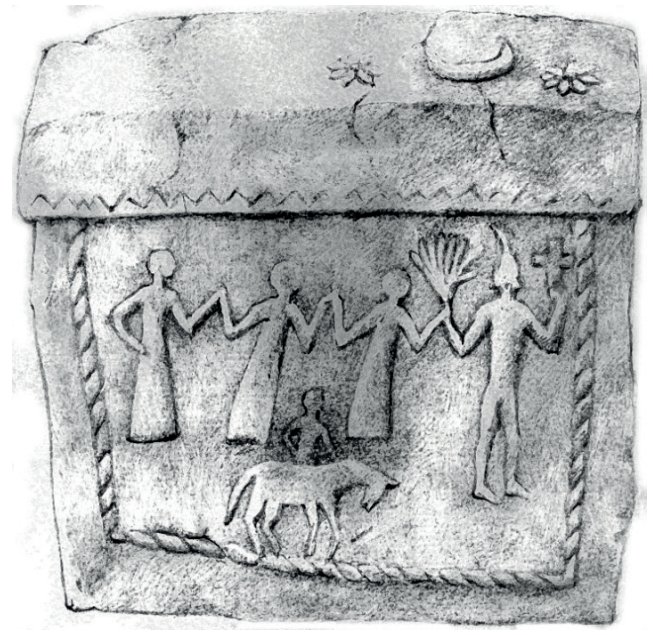

S1. 37.

Upravo spomenute pojedinosti, koje tom tipu kola atribuiraju jasna kršćanska značenja, upućuju istodobno i na simboličko značenje cijeloga znaka i na uzorak koji su ponavljali drugi klesari. U kršćanskoj likovnoj tradiciji, inače, postoje slične kompozicije. Biblijska priča o Abrahamovu gostoprimstvu bila je često prikazivana u minijaturama i na mozaicima (Sl. 38 i 39). Trojica putnika, zapravo trojica nebeskih anđela, koje je ugostio starac Abraham prikazuju se uvijek u dugim haljinama. ${ }^{22}$ Također, jedna minijatura iz rukopisa Biblije nazvane Cotton ilustrira treći dan stvaranja svijeta (Sl. 40). Ispred anđela s križem plešu tri djevojke. Radi se o personifikacijama božanske stvaralačke moći i tri dana. ${ }^{23}$

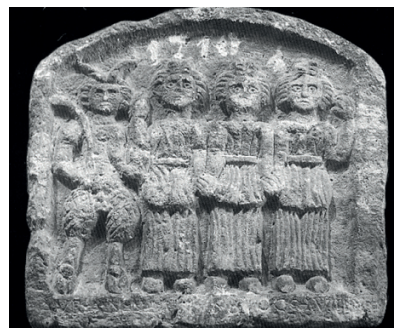

S1. 38 .

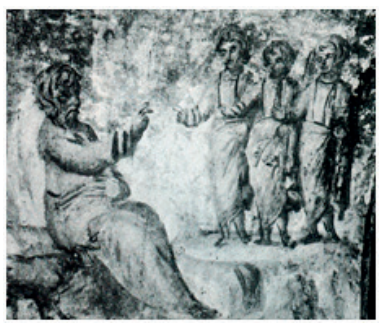

S1. 39.

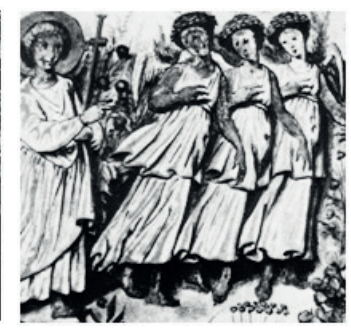

S1. 40.

22 Andrè Graber, Le vie della creazione nell'iconografia cristiana. Antichità e Medioevo, Jaca Book, Milano, 1988., sl. 74.

23 Isto, sl. 61. 
Ipak među najutjecajnijim kršćanskim nadahnućima takve likovne kompozicije priča je proroka Danijela (Dn 3) o trojici židovskih mladića koji se nisu htjeli klanjati zlatnom idolu babilonskoga kralja Nabukodonozora. Kad su bili optuženi, kralj im ponovo zaprijeti užarenom peći, ali mu oni odgovoriše da ih Bog njihov može izbaviti iz nje. Za kaznu ih kralj baci u oganj. Od vreline izgore kraljeve sluge koji su trojicu mladića bacili u peć, a oni blagoslivljahu pjesmom Boga, krećući se kroz plamenove. Kralj se s pratnjom iznenadi kada vidje u peći i četvrtu osobu koja mu je sličila "sinu Božjemu". Bio je to anđeo Gospodnji koji je sišao k mladićima, utrnuo oganj, zapravo ga pretvorio u blagi lahor, kako upućuje biblijski pisac. Mladići se spase neozlijeđeni pjevajući pjesmu hvale. Još u ranoj kršćanskoj ikonografiji u katakombama, pa onda tijekom srednjega vijeka, ilustrira se ta Danijelova priča na različite načine, zadržavajući uvijek trojicu mladića s uzdignutim rukama kao da u kolu igraju. Smisao toga likovnog prizora naglašavao je uvijek vjeru u Boga koji spašava duše pravednika.

Jedna takva ilustracija trojice mladića u užarenoj peći iz VI. stoljeća izrezbarena u reljefnom obliku sačuvana je na ploči od slonovače $s$ prikazima Kristovih čudesa, koja se čuva u Nacionalnom muzeju u Raveni (Sl. 41). Anđeo s križem u ruci gasi oganj, a trojica mladića s uzdignutim rukama u formi oranta stoje u ognju kao da igraju u kolu. ${ }^{24}$

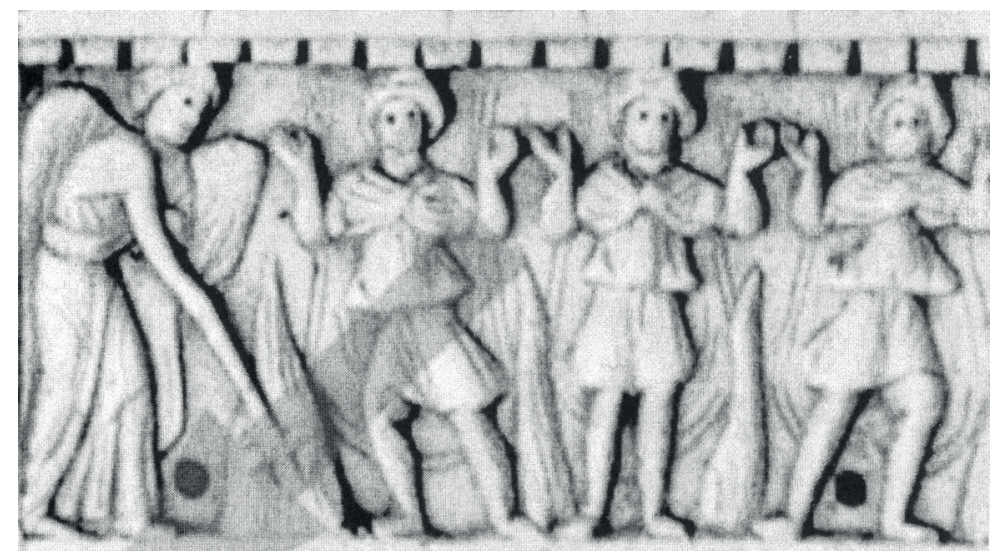

S1. 41.

24 W. F. Volbach, Early Christian Art, 1961., tabla 223. 
Reducira li se izrazito naglašena narativna protežnost predstave, ta bi ilustracija ili neka druga, njoj slična, mogla biti nadahnuće prizora na kasnosrednjovjekovnim spomenicima od Trilja do Boljuni. U tom smislu bila bi scena na sljemenjaku Jerka Kustražića s Ciste najbliža takvu nadahnuću i najpodatnija za komparaciju.

Anđeo je izgubio krila i postao vitez koji visinom nadmašuje ostale sudionike, i na ravenitanskom poliptihu i na nadgrobnom spomeniku. Ta odlika i križ koji drži uzdignut daje mu identitet uzvišene izdvojenosti i posvećenosti. Uzdignute ruke figura još uvijek čuvaju onu postojanost koju trojica Danijelovih drugova imaju na svim kršćanskim ilustracijama te teme. Njihov identitet mučeništva u gorućoj peći, u koju su dvaput bacani, ilustriran je palminom granom koju nosi prvi od trojice. U njoj bi likovi trojice mladića i anđela spasioca vjerojatno predstavljali nebesko kolo mučenika i anđela, na što upućuju i astralni motivi mladoga mjeseca i procvalih zvijezda iznad njih. Izgleda da je majstor toga spomenika posve shvaćao smisao biblijske teme koju je prilagodio svojoj uklesanoj priči, kako će oni koji su nepokolebljivi u svojoj vjeri biti istodobno spašeni od vječnoga ognja i nagrađeni društvom nebesnika. Njihovu kolu pridružio je klesar ili njegov crtač sjenku viteza Kostrenčića, zapravo njegovu nepropadljivu dušu, naznačenu samo crtom na klimavu zemaljskom konju.

Na tragu takva nadahnuća i značenja kompozicije kola mogle bi se interpretirati i one predstave u kojima kolovođa uzdiže križ, a broj se figura povećava ili smanjuje, kao na onom spomeniku koji prikazuje Škobalj na koricama svoje knjige ili na triljskom spomeniku s Pišteta. ${ }^{25}$

25 Marian Wenzel, Ukrasni motivi na stećcima, Veselin Masleša, Sarajevo, 1965., tab. XCV, 13. 


\title{
Bas relief of kolo* on medieval tombstones
}

\author{
Summary
}

The article analyses the pictogram of kolo on the representative late medieval tombstones, commonly referred to as stecak, from the perspective of the contemporary art tradition and esoteric texts, trying to decode their obscure original meaning. In such relationships, it is noted that different stylizations of kolo are presented in the manuscripts with both profane and spiritual contents, that is, their semantic extension is conditioned by the context. In this regard, the paper shows that numerous miniatures of kolo on the pages of the Novel on Alexander appear as the stylizations of fair and court feasts of illuminator's contemporaries, that the dance in The Romance of the Rose is actually an allegory of youth controlled by the flying Cupid. Also, in lavishly illuminated psalters, the apocalypse, Christian moralist codes, capitals and portals of Romanesque churches, the works of famous Italian painters of the $14^{\text {th }}$ and $15^{\text {th }} \mathrm{C}$., the form of kolo or dance, clearly shows saints, blesseds and angels in heavenly bliss.

As stecak belongs to funerary medieval European culture that was shaped within recognizable Christian eschatology, the article aims to match the pictorial symbols on the individual monuments to the esoteric meaning and value of the symbolic sign from the perspective of the art tradition. Typical Christian symbols such as palm twig or different versions of the cross in the hands of the dancers or with the picture of kolo, additionally intensify such meaning. The article shows that some of the bas reliefs were products of the sculptor's inventiveness, in which he depicted the basic representation of two angels with a raised cross or a cross-shaped sword known as the crux triunfans, with new silhouettes spread all over the stone or on the lateral sides of the monument as in Troskots near Mostar, or doubled as in the necropolis near Vostane. The representations of kolo with the scenes of duel are interpreted in the article as symbolic signs which, by combining agonists and inlixes, suggest Christian hope to save the soul of the deceased after its struggle with sin.

* kolo - circle dance 
The article is particularly concerned with the play of four dancers on the Jerko Kustrazic's tombstone from Cista, which was conveyed in various stylizations to the monuments of Trilj, Makarska and Boljuni, and claims that original inspiration was found in the biblical story of the prophet Daniel about the three Jewish youths who the angel of the Lord saved from the burning stove, relying on early medieval art illustrations of the same theme and their esoteric Christian meaning.

Keywords: context; sign; dance; eschatology; tombstone. 